\title{
Prevalence of Femoglobin Mutations and Hemoglobinopathies in Masjed Soleiman County, Southeastern Iran
}

Fatemeh Asadi (PhD Candidate) Department of Molecular Genetics, Science and Research Branch, Islamic Azad University, Fars, Iran

Department of Molecular Genetics, Marvdasht Branch, Islamic Azad University, Marvdasht, Iran

Seyedeh Moloud Rasouli Ghahfarokhi (Msc) Department of Nursing and Midwifery, Masjed-Soleiman Branch, Islamic Azad University, Masjed-Soleiman, Iran

Forough Talebi (PhD Candidate) Department of Midwifery, Faculty of Nursing and Midwifery, Tehran Medical Sciences Branch, Islamic Azad University, Tehran, Iran Corresponding author: Seyedeh Moloud Rasouli Ghahfarokhi Email: Rasoulinurse88@yahoo.com Tel: +9809166814903

Address: Masjed Soleiman Branch, Islamic Azad University, Masjed Soleiman, Iran

Received: 08 Aug 2018

Revised: 02 Oct 2018

Accepted: 14 Oct 2018

\section{(c) (1) (3)}

This work is licensed under a Creative Commons Attribution 4.0 License.

\section{ABSTRACT}

Background and Objectives: Hemoglobinopathies are characterized by defects in the synthesis of globin chains of hemoglobin (Hb). The purpose of the present study was to evaluate mutations associated with thalassemia and other hemoglobinopathies in Masjed Soleiman County, Iran.

Methods: This descriptive study was carried out on 456 individuals suspected of having hemoglobinopathies who were referred to health centers of the Masjed Soleiman Country in 2015-2017. Blood samples were collected in EDTA tubes. Complete blood count test was performed and red blood cell indices were determined. Level of Hb variants was measured using capillary electrophoresis. Reverse dot-blot, gap-polymerase chain reaction and Sanger sequencing were carried out to detect mutations.

Results: We found that $17.7 \%$ of the subjects were heterozygous for $\beta$-thalassemia. Frequency of mutations $36 / 37(-\mathrm{T})$, IVS-II-I ( $\mathrm{G}>\mathrm{A})$ and IVS-I-110 ( $\mathrm{G}>\mathrm{A})$ in the $\beta$-globin gene was $26.7 \%, 22 \%$ and $16.27 \%$, respectively. In addition, $9.5 \%$ of the subjects contained $\mathrm{Hb} \mathrm{S}$, Hb $\mathrm{D}$ and $\mathrm{Hb} \mathrm{C}$, while $1.1 \%$ of the subjects showed co-inheritance of an Hb variant and $\beta$-thalassemia. In subjects with $\alpha$-thalassemia, the $-\alpha 3.7$ (57.1\%), -- NEn-(17.4\%), - $\alpha^{4.2}$ $(3.1 \%)$ and $-\alpha^{20.5}(1.5 \%)$ deletions were found as the most prevalent mutations.

Conclusion: In addition to the high prevalence of $\beta$-thalassemia and HBB gene mutations, we detected variants $\mathrm{Hb} S$, Hb $\mathrm{D}$, Hb $\mathrm{C}$ and c0-inheritance of an Hb variants and $\beta$ thalassemia in individuals living in the Masjed Soleiman Country. We also identified four mutations in the $\alpha$-globin gene. These results can be useful for genetic counseling in this population.

KEYWORID: Hemoglobinopathies, $\beta$-Thalassemia, $\alpha$-Thalassemia, mutation, HB variant. 


\section{INTRODUCTION}

Hemoglobinopathies are among the most prevalent inherited disorders around the world. The hemoglobin $(\mathrm{Hb})$ molecule in humans is made up of two pairs of unlike globin chains designated as $\alpha, \beta, \gamma$ and $\delta$ (1). $\mathrm{Hb}$ disorders are classified into thalassemia syndromes ( $\alpha$ - and $\beta$-thalassemia) and structural $\mathrm{Hb}$ variants. Approximately $7 \%$ of the world's population carry an abnormal Hb gene, and about 300,000500,000 infants are born with clinically significant $\mathrm{Hb}$ disorders every year (2). Thalassemia is more prevalent in the Mediterranean region, North and West Africa, the Middle East, the Indian subcontinent, southern Far East and southeastern Asia. Iran is a high-incidence region for $\beta$-thalassemia, but the incidence rates vary from one area to another. For instance, the prevalence of $\beta$ thalassemia trait is above $10 \%$ near the Caspian Sea and the Persian Gulf and about 4$8 \%$ in other areas of Iran (3). B-thalassemia results from mutations in the $H B B$ gene cluster which is located on the short arm of chromosome.

More than $300 \quad \beta$-thalassemia-causing mutations and $1,000 \mathrm{Hb}$ variants have been identified(http://globin.cse.psu.edu/hbvar/men u.html). In Iran, there are about 25,000 $\beta$ thalassemia patients and 2 million carriers (4). In addition, 50 different mutations have been detected in different populations of Iran. According to studies, the prevalence of $\beta$ thalassemia is higher in the northern parts of Iran $(4,5)$. Abnormal manufacturing or absent of $\alpha$-globin chains causes $\alpha$-thalassemia. The $\alpha$-globin gene loci are duplicated $(\alpha \alpha / \alpha \alpha)$. Athalassemia carriers are individuals without the two $\alpha$-globin genes $(--/ \alpha \alpha$ or $-\alpha /-\alpha)$ that have smaller red blood cell (RBCs) and a lower RBC count (mild anemia). However, loss of three $\alpha$-globin genes $(--/-\alpha)$ results in $\mathrm{Hb} \mathrm{H}$ disease. Hb Bart's hydrops fetalis syndrome is caused by deletion of all four $\alpha$ globin genes (6).

Structural $\mathrm{Hb}$ variants result from point mutations in the $\alpha$ - or $\beta$-globin genes. The most widespread variants in the world are $\mathrm{Hb}$ $\mathrm{S}, \mathrm{Hb} \mathrm{C}, \mathrm{Hb} \mathrm{E}$ and $\mathrm{Hb}$ D-Punjab (7).

Different ethnic groups and tribes live in the Khuzestan Province, Iran. It has been reported that the prevalence of $\alpha$ - and $\beta$-thalassemia as well as $\mathrm{Hb} \mathrm{S}, \mathrm{Hb} \mathrm{C}$ and $\mathrm{Hb} \mathrm{D}$ is high in this province (8). Bakhtiari people are the predominant ethnic group that resides in the Masjed Soleiman County in the Khuzestan Province, and consanguineous marriage is a common custom among this ethnic group. In this study, we aimed to evaluate the prevalence of hemoglobinopathies in the Masjed Soleiman, Iran.

\section{MATERIALS AND METHODS}

The study included 456 individuals suspected of having anemia and hemoglobinopathies who were referred to health centers of Masjed Soleiman in 20152017. Blood samples were collected in EDTA tubes. Screening for hemoglobinopathies included complete blood count, $\mathrm{Hb}$ electrophoresis and measurement of $\mathrm{Hb} \mathrm{A} 2$ level. The standard diagnostic marker for $\beta$ thalassemia is elevation of the $\mathrm{Hb} \mathrm{A} 2$ level (3.5\%). Complete blood count was carried out with an automated hematology analyzer (Sysmex KX-21 N, Kobe, Japan). Quantification of $\mathrm{Hb} \mathrm{A} 2, \mathrm{Hb} \mathrm{F}, \mathrm{Hb} \mathrm{A}$ and other $\mathrm{Hb}$ variants was performed using Sebia Minicap (France) according to the manufacturer's instructions. The Minicap system uses the principle of capillary electrophoresis in free solution and automatically produces one electropherogram (9).

Genomic DNA was extracted from whole blood leukocytes using the QIAamp DNA Blood Mini Kit (Qiagen, Hilden, Germany). Reverse dot-blot hybridization analysis was performed using $\beta$-Globin Strip Assay SEA ${ }^{\mathrm{TM}}$ (ViennaLab Diagnostics, Vienna, Austria) according to the manufacturer's instructions to screen for common $\beta$-globin gene mutations. The results were then validated with amplification refractory mutation systempolymerase chain reaction (ARMS-PCR) (10). For this purpose, primers were designed according to previous studies $(4,11)$. In patients without mutation, Sanger sequencing was performed to identify undetected mutations. DNA was amplified by PCR using specific primers as described by Galehdari et al., and PCR products were sequenced with an ABI 3730 DNA analyzer (Applied Biosystems Inc., CA, USA) (12). Individuals with low mean corpuscular volume $(\mathrm{MCV}<80.0 \mathrm{fL})$, mean cell $\mathrm{Hb}(\mathrm{MCH})$ of less than $27.0 \mathrm{pg}$, normal $\mathrm{Hb} \mathrm{A} 2$ and normal iron levels were suspected to be $\alpha$-thalassemia carriers. 
Multiplex Gap-PCR was used to screen for $\alpha$ thalassemia mutations and common deletions in Iran (-- ${ }^{\text {MED }},-\mathrm{a}^{3.7},-\alpha^{20.5}$ and $\left.-\mathrm{a}^{4.2}\right)(13,14)$. For subjects without mutation in the multiplex Gap-PCR, ARMS-PCR was first performed to screen $-\alpha^{\mathrm{CD} 19}, \alpha^{\mathrm{CS}}$ and $\alpha^{5 \mathrm{nt}}$ deletion. If no mutation was detected, DNA sequencing was done to identify unknown mutations. Statistical analysis was performed using SPSS software (version 18.0).

\section{RESULTS}

Among the 456 subjects, 81 subjects (17.7\%) had low MCV and MCH levels and $\mathrm{Hb} \mathrm{A} 2$ of less than $3.5 \%$, and thus were identified as $\beta$-thalassemia carriers. It was found that $8.4 \%$ of individuals were heterozygous for $\mathrm{Hb} \mathrm{S}, \mathrm{Hb} \mathrm{D}, \mathrm{Hb} \mathrm{C}$ and $\mathrm{Hb}$ Barts. In addition, $1.1 \%$ of the subjects showed co-inheritance of an $\mathrm{Hb}$ variant and $\beta$ thalassemia. Table 1 represents the mean values of RBC parameters and table 2 show the distribution of $\mathrm{Hb}$ variants.

Genetic analysis of the $H B B$ gene revealed eight mutations among which 36/37 (-T), IVSII-1 (G>A) and IVS-I-110 (G>A) with respective frequencies of $26.7 \%, 22 \%$ and $16.27 \%$ were the most common mutations. Other frequent mutations were IVS- II745 $(\mathrm{C}>\mathrm{G}), \quad 5 \mathrm{UTR}+20(\mathrm{C}>, \mathrm{CD} 82 / 83(-\mathrm{G}), \quad \mathrm{Fr}$ $8 / 9(+\mathrm{G})$ and CD39 $(\mathrm{C}>\mathrm{T})$. Frequency of mutant $H B B$ alleles is presented in table 3 . Mutations found in the $H B B$ gene for $\mathrm{Hb} \mathrm{S}, \mathrm{Hb}$ $\mathrm{D}$ and $\mathrm{Hb} \mathrm{C}$ were c.20 $\mathrm{A}>\mathrm{T}, \mathrm{c} .67 \mathrm{G}>\mathrm{C}$ and c.19G>A, respectively.

Moreover, 63 subjects (13.8\%) were suspected cases of $\alpha$-thalassemia. The $-\alpha 3.7$ $(57.1 \%),--$ MED $-(17.4 \%),-\alpha^{4.2}(3.1)$ and $-\alpha^{20.5}$ (1.5\%) deletions were also detected in the suspected cases (figure 1), and no mutation was found in 12 cases. Table 4 shows the frequency of $\beta$-thalassemia mutations in different cities of the Khuzestan Province, Iran.

Table 1- Mean ( \pm SD) values of RBC parameters and $\mathrm{Hb}$ fractions in variants detected by capillary zone electrophoresis

\begin{tabular}{|c|c|c|c|c|c|c|}
\hline Variant & Frequency $(\%)$ & MCV (fL) & MCH (pg) & Hb A (\%) & $\begin{array}{c}\text { Hb A2 } \\
(\%)\end{array}$ & Hb F (\%) \\
\hline Hb S carrier & $17(3.7 \%)$ & $81.3 \pm 7.6$ & $26.8 \pm 4.8$ & $81.2 \pm 4.8$ & $2.3 \pm 0.6$ & $1 \pm 0.4$ \\
\hline Hb D carrier & $11(2.4 \%)$ & $83.3 \pm 5.6$ & $27.5 \pm 2.9$ & $78.7 \pm 1.6$ & $1.9 \pm 1.3$ & $3.2 \pm 0.2$ \\
\hline Hb C carrier & $9(1.9 \%)$ & $82.3 \pm 9.6$ & $29.2 \pm 3.8$ & $73.2 \pm 5.7$ & $3.1 \pm 1.1$ & $2.7 \pm 0.7$ \\
\hline \multirow[t]{10}{*}{ Hb Barts } & $2(4 \%)$ & $72.5 \pm 3.6$ & $22.2 \pm 1.5$ & $77.4 \pm 7.2$ & $2.1 \pm 0.5$ & - \\
\hline & \multicolumn{6}{|c|}{ Table 2- Distribution of Hb variants } \\
\hline & \multicolumn{2}{|c|}{ Hb variant } & \multicolumn{2}{|c|}{$\begin{array}{c}\text { Number of } \\
\text { hemoglobinopathy cases } \\
(\%)\end{array}$} & \multicolumn{2}{|c|}{$\begin{array}{l}\text { Percent among all studied } \\
\text { cases }\end{array}$} \\
\hline & \multicolumn{2}{|c|}{ Hb S trait (HbAS) } & \multicolumn{2}{|c|}{$17(38 \%)$} & \multicolumn{2}{|l|}{$3.7 \%$} \\
\hline & \multicolumn{2}{|c|}{ Hb S- $\beta$-thalassemia } & \multicolumn{2}{|c|}{$3(6.9 \%)$} & \multicolumn{2}{|c|}{$0.65 \%$} \\
\hline & \multicolumn{2}{|c|}{ Hb C trait (HbAC) } & \multicolumn{2}{|c|}{$9(20 \%)$} & \multicolumn{2}{|l|}{$1.9 \%$} \\
\hline & \multicolumn{2}{|c|}{ Hb D trait (HbAD) } & \multicolumn{2}{|c|}{$11(25 \%)$} & \multicolumn{2}{|l|}{$2.4 \%$} \\
\hline & \multicolumn{2}{|c|}{ Hb C- $\beta$-thalassemia } & \multicolumn{2}{|c|}{$2(4.5 \%)$} & \multicolumn{2}{|c|}{$0.44 \%$} \\
\hline & \multicolumn{2}{|c|}{ Hb Barts } & \multicolumn{2}{|c|}{$2(4.5 \%)$} & \multicolumn{2}{|c|}{$0.44 \%$} \\
\hline & \multicolumn{2}{|c|}{ Total } & \multicolumn{2}{|c|}{$44(100 \%)$} & \multicolumn{2}{|l|}{$9.5 \%$} \\
\hline
\end{tabular}

Figure 1- Multiplex-Gap PCR analysis of $\alpha$-globin gene on agarose gel electrophoresis. Lane 1 (left to right): DNA marker, lane 2: normal $\alpha$-globin gene (control), lane 3: $\alpha^{3.7}$ deletion (2022 bp), lane 4: $\alpha^{4.2}\left(1628\right.$ bp) and lane 5: ${ }^{\mathrm{MED}}(807 \mathrm{bp})$.

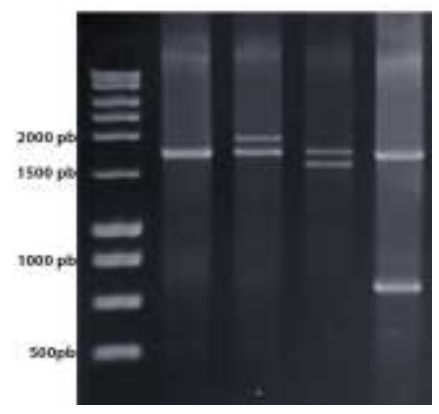


Table 3- Frequency of HBB gene mutations

\begin{tabular}{ccccc}
\hline Mutation & Type & Mutant allele & Origin of mutation & Frequency (\%) \\
\hline CDs 36/37 (-T) & $\beta^{0}$ & 23 & Kurdish, Iranian & 26.7 \\
IVSII-1 (G>A) & $\beta^{0}$ & 19 & Mediterranean & 22 \\
IVSI-110 (G>A) & $\beta^{+}$ & 14 & Mediterranean & 16.27 \\
CD82/83 (-G) & $\beta^{+}$ & 11 & Mediterranean & 12.7 \\
5UTR+20 (C>T) & $\beta^{+}$ & 7 & Iranian & 8.1 \\
IVS II-745 (C>G) & $\beta^{+}$ & 6 & Kurdish & 6.97 \\
Fr 8/9 (+G) & $\beta^{0}$ & 3 & Asian, Indian & 3.48 \\
CD39 $(\mathrm{C}>$ T) & $\beta^{0}$ & 3 & Mediterranean & 3.48 \\
Total & & 86 & & $100 \%$ \\
\hline
\end{tabular}

Table 4-Percentage frequency distribution of mutations in $\beta$-thalassemia subjects in different cities of the Khuzestan Province, Iran

\begin{tabular}{|c|c|c|c|c|c|c|}
\hline Mutation & $\begin{array}{c}\text { Masjed } \\
\text { Soleiman }\end{array}$ & $\begin{array}{c}\text { Eizeh and Baq- } \\
\text { Malek }\end{array}$ & Shadegan & Abadan & Shushtar & Ahvaz \\
\hline CDs 36/37 (-T) & $26.7 \%$ & $22.70 \%$ & $38.61 \%$ & $15 \%$ & $23.4 \%$ & $20.54 \%$ \\
\hline IVS-II-1 (G>A) & $22 \%$ & $19.23 \%$ & $24.75 \%$ & $25 \%$ & $23.4 \%$ & $20.01 \%$ \\
\hline IVS-I-110(G>A) & $16.27 \%$ & $8.46 \%$ & $5.94 \%$ & $16 \%$ & $10 \%$ & $14.18 \%$ \\
\hline CD 82/83 (-G) & $12.7 \%$ & 0.0 & $1.98 \%$ & 0.0 & $9 \%$ & $2.1 \%$ \\
\hline IVS- II-745(C>G) & $6.97 \%$ & $11.53 \%$ & $1.60 \%$ & 0.0 & $0.9 \%$ & $1.3 \%$ \\
\hline $5^{\prime} \mathrm{UTR}+20(\mathrm{C}>\mathrm{T})$ & $8.1 \%$ & $11.53 \%$ & 0.0 & 0.0 & $0.9 \%$ & $1 \%$ \\
\hline CD 8/9 (+G) & $3.48 \%$ & $0.0 \%$ & $1.98 \%$ & 0.0 & 0.0 & $3 \%$ \\
\hline $\operatorname{CD39}(\mathrm{C}>\mathrm{T})$ & $3.48 \%$ & $1.54 \%$ & $0.99 \%$ & $5 \%$ & $9 \%$ & $3.50 \%$ \\
\hline
\end{tabular}

\section{DISCUSSION}

Hemoglobinopathies include thalassemia and structural variants of $\mathrm{Hb}(\mathrm{Hb} \mathrm{S}, \mathrm{Hb} \mathrm{C}$ and $\mathrm{Hb} \mathrm{E)} \mathrm{that} \mathrm{result} \mathrm{from} \mathrm{defects} \mathrm{in} \mathrm{the} \mathrm{synthesis}$ of the globin chains. Iran is a multi-ethnic state that shows heterogeneity in $\mathrm{Hb}$ variants and thalassemia mutations. The Khuzestan Province in southeast of Iran also encompasses various ethnic groups including Arab, Persian, Bakhtiari and Lurs, and has a high prevalence of $\alpha$ - and $\beta$ - thalassemia mutations (19). So far, 42 different $\beta$-thalassemia mutations and several common $\beta$-globin variants including, $\mathrm{Hb} \mathrm{S}, \mathrm{Hb} \mathrm{C} \mathrm{Hb}$ D-Punjab Hb O-Arab, Hb E and $\mathrm{Hb}$ J-Iran have been identified $(4,8,12$, $15,16)$.
$\mathrm{Hb} \mathrm{S}$ is produced by a point mutation in the $H B B$ gene. Clinical features of $\mathrm{Hb} \mathrm{S}-\beta$ thalassemia are variable, ranging from a completely asymptomatic state to a severe disorder that is similar to homozygous sickle cell disease. The prevalence of this condition is high in south of Iran, particularly the Khuzestan Province (16).

$\mathrm{Hb} \mathrm{D}$ is a $\beta$-chain variant that is mainly found in northwest India, Pakistan and Iran (17). It may be co-inherited with $\mathrm{Hb} S$ or $\beta$ thalassemia. The co-inheritance of $\beta$ thalassemia and $\mathrm{Hb} \mathrm{D}$ can result in a slightly lower $\mathrm{Hb}$ level. 
$\mathrm{HbC}$ is another variant in which lysine replaces glutamic acid in the sixth position of the $\beta$-globin chain. Individuals with $\mathrm{Hb} \mathrm{C}$ trait $(\mathrm{Hb} \mathrm{AC})$ are phenotypically normal, while those with $\mathrm{Hb} \mathrm{C}$ disease ( $\mathrm{Hb} \mathrm{CC}$ ) may have a mild degree of hemolytic anemia and splenomegaly (18).

In the present study, $17.7 \%$ of the subjects were $\beta$-thalassemia carriers and had eight different types of $\beta$-thalassemia mutations. Among these mutations, frequency of $\mathrm{CDs}$ 36/37 (-T), IVS-II-1 (G>A) and IVS-I-110 $(\mathrm{G}>\mathrm{A})$ was higher. In addition, $\mathrm{Hb} \mathrm{S}, \mathrm{Hb} \mathrm{D}$ and $\mathrm{Hb} \mathrm{C}$ were identified as the most prevalent abnormal $\mathrm{Hb}$ variants. The genetic analysis of these variants revealed the following mutations in the $H B B$ gene: c.20A>T (3.7\%), c. $67 \mathrm{G}>\mathrm{C}(2.4 \%)$ and c $.19 \mathrm{G}>\mathrm{A}(1.9 \%)$ in $\mathrm{Hb}$ $\mathrm{S}, \mathrm{Hb} \mathrm{D}$ and $\mathrm{Hb} \mathrm{C}$, respectively. Moreover, coinheritance of an $\mathrm{Hb}$ variant and $\beta$-thalassemia was found in $1.1 \%$ of the subjects.

In a study by Galehdari et al. (2011) in the Khuzestan Province, the most frequent mutations were CD 36/37 (-T) (20.4\%), IVSII-1 (G>A) (20.0\%) and IVS-I-110 (G>A) (14.2\%), and $\mathrm{Hb} \mathrm{S}, \mathrm{Hb} \mathrm{D}$ and $\mathrm{Hb} \mathrm{C}$ were reported as the most prevalent variants (12). Another study in the Khuzestan Province reported CD 36/37 (-T) and IVS II-1 (G>A) as the most common mutations with frequency of $13.9 \%$ and $10.4 \%$, respectively (20). Similar to our findings, in the mentioned study, $0.5 \%$ of subjects showed co-inheritance of $\mathrm{HbS}$ and $\beta-$ thalassemia.

The CDs 36/37 mutation was reported as the most common mutation in the Lorestan (33.8\%) and Isfahan (19.7\%) provinces (21, 22 ), which is similar to our results. Studies in north and west of Iran reported IVS-II-I as the most common mutation $(15,23)$.

In our study, the most common mutations were CD 82/83(-G), 5UTR+20(C>T) and IVS II$745(\mathrm{C}>\mathrm{G})$. However, these mutations have been rarely detected in other provinces of Iran. We identified the $-\alpha^{3.7}$ deletion $(57.1 \%)$ as the most common mutation in the $\alpha$-globin gene, which is consistent with results of previous studies in Iran (25-27). Other mutations detected in our study included - ${ }^{\text {MED }}(17.4 \%)$, $\alpha^{4.2}(3.1 \%)$ and $-\alpha^{20.5}(1.5 \%)$. Moreover, 12 subjects showed no mutation in the $\alpha$-globin gene.

The most common deletions observed in $\alpha$ - thalassemia patients included $-\alpha^{3.7},-\alpha^{4.2},--{ }^{\text {MED }}$ and -- ${ }^{\text {SEA }}$ deletions (24). In Iran, the most common mutation are $-\alpha^{3.7},-\alpha^{4.2},-\alpha^{20.5}$ and -MED deletions $(16,28,29)$.

In a study by Khosravi et al., the $-\mathrm{a}^{3.7}$ and -MED deletions were reported as the most common mutations in the Bakhtiari population of the Khuzestan Province (30). Hossieni Nejad et al. conducted a study on $\alpha$ - and $\beta$ globin gene mutations in Abadan and Khorramshahr (Khuzestan Province) and reported IVSII-I as the most prevalent mutation (31), which is inconsistent with our findings. Similar to our study, a study in city of Shadegan (Khuzestan Province) detected CD 36/37(-T) (38.61\%) and $-\alpha 3.7 / \alpha \alpha(52.99 \%)$ as the most common mutations among $\beta$ thalassemia and $\alpha$-thalassemia carriers, respectively (32). In study of Sayahi et al. on spectrum of thalassemia among voluntary couples in city of Shushtar, CD 36/37 (-T), IVSII-1 (G>A) and IVSI-110 (G>A) were identified as the most common mutations (33). In this study, we used capillary zone electrophoresis for the detection of hemoglobinopathies. Joshaghani et al. used the same technique for detection of $\mathrm{Hb}$ abnormalities in north of Iran, and identified the $\mathrm{Hb} \mathrm{S}(55 \%), \mathrm{Hb} \mathrm{H}(27 \%), \mathrm{Hb}$ Barts (41\%), $\mathrm{Hb} \mathrm{D}(4.68 \%)$ and $\mathrm{Hb} \mathrm{E}(2.7 \%)$ variants (34). These findings are in line with our results except for the $\mathrm{Hb} \mathrm{E}$, which was not detected in our subjects.

\section{CONCLUSION}

In addition to the high prevalence of $\beta$ thalassemia and $H B B$ gene mutations, we detected $\mathrm{Hb}$ variants $\mathrm{Hb} \mathrm{S}, \mathrm{Hb} \mathrm{D}, \mathrm{Hb} \mathrm{C}$ and co-inheritance of $\mathrm{Hb}$ variants and $\beta$ thalassemia in individuals from the Masjed Soleiman Country in the Khuzestan Province, Iran. We also identified four mutations in the $\alpha$-globin gene. These results can be useful for genetic counseling in this population.

\section{ACKNOWLEDGEMENTS}

This research was funded by the Islamic Azad University, Masjed-Soleiman Branch, Iran.

\section{CONFLICT OF INTEREST}

The authors declare that there is no conflict of interest. 


\section{REFERENCES}

1. Weatherall D, Akinyanju O, Fucharoen S, Olivieri N, Musgrove P. Inherited Disorders of Hemoglobin. In: Jamison DT, Breman JG, Measham AR, Alleyne G, Claeson M, Evans DB, et al., editors. Disease Control Priorities in Developing Countries. 2nd ed. Washington (DC) 2006 .

2. Weatherall DJ, Clegg JB. The thalassaemia syndromes: John Wiley \& Sons; 2008.

3. Ali D, Mehran K, Moghaddam AG. Comparative evaluation of renal findings in Beta-thalassemia major and intermedia. Saudi Journal of Kidney Diseases and Transplantation. 2008;19(2):206.

4. Najmabadi $H$, Karimi-Nejad $R$, Sahebjam $S$, Pourfarzad F, Teimourian S, Sahebjam F, et al. The $\beta$ thalassemia mutation spectrum in the Iranian population. 2001;25(3):285-96.

5. Abolghasemi H, Amid A, Zeinali S, Radfar MH, Eshghi P, Rahiminejad MS, et al. Thalassemia in Iran: epidemiology, prevention, and management. 2007;29(4):233-8.

6 . Higgs DRJCSHpim. The molecular basis of $\alpha$ -

7. S. H, Jalalifar., A. KJM, K. J, N. S. A Review of Rare Hemoglobinopathies in Iran G3M. 2013;11(3):3206-17.

8. K. Z, M. P, B. K. The Diagnosis and Frequency of Beta and Alpha Thalassemia Mutations and other C, D, and $\mathrm{S}$ Common Hemobinopathies in Ahvaz Volunteer Patients. Persian Journal of Medical Sciences (PJMS). $2015 ; 1$.

9. Cotton F, Malaviolle X, Vertongen F, Gulbis B. Evaluation of an automated capillary electrophoresis system in the screening for hemoglobinopathies. Clinical laboratory. 2009;55(5-6):217-21.

10. Hassan S, Ahmad R, Zakaria Z, Zulkafli Z, Abdullah $\mathrm{WZ}$.Detection of $\beta$-globin gene mutations among $\beta$ thalassaemia carriers and patients in Malaysia: application of multiplex amplification refractory mutation system-polymerase chain reaction. The Malaysian journal of medical sciences: MJMS. 2013;20(1):13

11. Old J, Varawalla N, Weatherall D. Rapid detection and prenatal diagnosis of $\beta$-thalassaemia: studies in Indian and Cypriot populations in the UK. The Lancet. 1990;336(8719):834-7.

12. Galehdari H, Salehi B, Azmoun S, Keikhaei B, Zandian KM, Pedram M. Comprehensive spectrum of the $\beta$-thalassemia mutations in Khuzestan, Southwest Iran. Hemoglobin. 2010;34(5):461-8.

13. Chong SS, Boehm CD, Higgs DR, Cutting GRJB. Single-tube multiplex-PCR screen for common deletional determinants of $\alpha$-thalassemia. 2000;95(1):3. r . .

14. Kiani-Shirazi R, Zainali S, Karimipoor $M$, Alibakhshi BZRJTUMJ. PCR Application In Reognition Of Prevelant Deletion Of $\alpha$ Globin Gene In Alpha Thalasemia Carriers. 2006;64(2):1-2

15. Derakhshandeh-Peykar P, Akhavan-Niaki H, Tamaddoni A, Ghawidel-Parsa S, Holakouie Naieni K, Rahmani $M$, et al. Distribution of $\beta$-thalassemia mutations in the northern provinces of Iran. Hemoglobin. 2007;31(3):351-6.

16. Zandian K, Nateghi J, Keikhaie B, Pedram M, Hafezi-Nejad N, Hadavi V, et al. $\alpha$-thalassemia mutations in Khuzestan Province, Southwest Iran. Hemoglobin. 2008;32(6):546-52.
17. Saleh-gohari N, Mohammadi-Anaie M. CoInheritance of Sickle Cell Trait and Thalassemia Mutations in South Central Iran. Iranian Journal of Public Health. 2012;41(10):81-6.

18. Piel FB, Howes RE, Patil AP, Nyangiri OA, Gething $\mathrm{PW}$, Bhatt $\mathrm{S}$, et al. The distribution of haemoglobin $\mathrm{C}$ and its prevalence in newborns in Africa. Scientific reports. 2013;3:1671.

19. Saadat M, Ansari-Lari M, Farhud DD. Consanguineous marriage in Iran. Annals of human biology. 2004;31(2):263-9.

20. Dehghanifard A, Shahjahani M, Galehdari H, Rahim F, Hamid F, Jaseb K, et al. Prenatal diagnosis of different polymorphisms of $\beta$-globin gene in Ahvaz. International journal of hematology-oncology and stem cell research. 2013;7(2):17.

21. Kiani AA, Mortazavi Y, Zeinali S, Shirkhani Y. The molecular analysis of $\beta$-thalassemia mutations in Lorestan Province, Iran. Hemoglobin. 2007;31(3):343-9.

22. Derakhshandeh-Peykar P, Hourfar H, Heidari M, Kheirollahi M, Miryounesi M .The spectrum of $\beta$ thalassemia mutations in Isfahan Province of Iran. Iranian Journal of Public Health. 2008;37(2):106-11.

23. Haghi M, Khorshidi S, Hosseinpour Feizi MA, Pouladi N, Hosseinpour Feizi AA. $\beta$-Thalassemia mutations in the Iranian Kurdish population of Kurdistan and West Azerbaijan provinces. Hemoglobin. 2009;33(2):109-14.

24. Chong SS, Boehm CD, Higgs DR, Cutting GR. Single-tube multiplex-PCR screen for common deletional determinants of $\alpha$-thalassemia. Blood. 2000;95(1):360-2.

25. Dehbozorgian J, Moghadam M, Daryanoush S, Haghpanah S, Imani fard J, Aramesh A, et al. Distribution of alpha-thalassemia mutations in Iranian population. Hematology. 2015;20(6):359-62.

26. Gohari LH, Petrou M, Felekis X, Christopoulos G, Kleanthous M. Identification of $\alpha$-Thalassemia Mutations in Iranian Individuals with Abnormal Hematological Indices and Normal $\mathrm{Hb}$ A2. Hemoglobin. 2003;27(2):129-32.

27. Valaei A, Karimipoor M, Kordafshari A, Zeinali SJIbj. Molecular Basis of $\alpha$-Thalassemia in Iran. 2018;22(1):6.

28. Rahim F. Correlation of beta-thalassemia mutations with alpha-thalassemia: an experience of the southwestern region of Iran. Hematology. 2010;15(6):430-3.

29. Tamaddoni A, Hadavi V, Nejad NH, Khosh-Ain A, Siami R, Aghai-Meibodi J, et al. $\alpha$-Thalassemia mutation analyses in Mazandaran province, North Iran. Hemoglobin. 2009;33(2):115-23.

30 .Khosravi A, Jalali-Far M, Saki N, Hosseini H, Galehdari H, Kiani-Ghalesardi O, et al. Evaluation of $\alpha-$ globin gene mutations among different ethnic groups in Khuzestan Province, Southwest Iran. Hemoglobin. 2016;40(2):113-7.

31. Hosseini Nejad F, Keikhaei B, Mohammadi Doust M, Hosseini Nejad K. Assessment of Genetic Variation of alfa-and beta-Thalassemia Disorder among Marriage Applicants in Abadan and Khorramshahr. Jundishapur Scientific Medical Journal. 
32. Irani AD, Cheraghi Z, Bitaraf S, Cheraghi P, Safiri S. Prevalence of alpha and beta-thalassemia mutations among carriers of thalassemia in Shadegan city, southwest of Iran. Zahedan Journal of Research in Medical Sciences. 2015;17(8).

33. Sayahi M, Mardasi FG, Kambo MS. Thalassemia Spectrum and Prenatal Diagnosis among Voluntary Couples in Shushtar City, during a Five Year Period. Gene, Cell and Tissue. 2017(In Press).
34. HR. J, S. P, Kh. K, N. B, H. J, AA. A, et al . ]Hemoglobin D is the most Common Hemoglobinopathy in the North of Iran]. mljgoums. 2015;9(5):28-32. 